\title{
Effect of liquid smoke on microbiological and physico-chemical properties of beef meatballs during storage
}

\author{
*Indiarto, R., Nurhadi, B., Tensiska, Subroto, E. and Istiqamah, Y.J. \\ Department of Food Industrial Technology, Faculty of Agro-Industrial Technology, Universitas \\ Padjadjaran, Jalan Raya Bandung-Sumedang Km. 21, Jatinangor, Sumedang 40600, Indonesia
}

\begin{abstract}
Article history:
Received: 15 October 2019

Received in revised form: 30

October 2019

Accepted: 12 November 2019

Available Online: 9

December 2019
\end{abstract}

\section{Keywords:}

Wood pyrolysis,

Hardness,

Springiness,

Cohesiveness,

Gumminess,

Preservative

\section{DOI:}

https://doi.org/10.26656/fr.2017.4(2).341

\begin{abstract}
Meatballs beef is a processed-meat product which has distinctive texture characteristic and is classified as perishable food products. Microbiological and physico-chemical properties are essential factors in determining the quality of meat products, and one of the things affecting the quality is the interaction between smoke and food components. The objective of this study was to evaluate the effect of liquid smoke on the microbiological and physico -chemical properties of beef meatballs during storage. The research method used explanatory research with five treatments and three replications and analyzed with a regression model. Beef meatballs without the addition of liquid smoke were used as controls, while the addition of liquid smoke $1.0 \%, 1.5 \%, 2.5 \%, 2.5 \%$, and $3.0 \%$ were used as treatments. The parameters analyzed consisted of $\mathrm{pH}$, total microbial number, color, and texture profile of beef meatballs. The storage time significantly has a negative effect on the $\mathrm{pH}$ value but has a positive effect on the total microbial number and texture parameters (hardness, springiness, cohesiveness, and gumminess). Increased liquid smoke concentrations in beef meatballs can significantly reduce microbe damage, maintain texture during storage, and increase the total color difference. Liquid smoke can be used as a natural preservative alternative, which is safe for beef meatballs. However, it must be considered about consumers' preference for the smoky aroma and flavor obtained.
\end{abstract}

\section{Introduction}

Meatballs are a popular processed meat product in Indonesia. Meatballs are classified as perishable food products. Among the types of meatballs (fish, chicken, pork, and beef), beef meatballs are the most widespread and most commonly consumed by Indonesian people; they are usually served with noodles or vermicelli, vegetables, and gravy. Meatballs are sphere-shaped meat product or other shapes made of a mixture of meat and starch with or without Permitted Food Additives; the meatballs should contain at least 50\% meat (Turhan et al., 2014).

The media has reported that there are many foods in the market containing dangerous food additives consists of borax and formalin. Borax is a compound that can improve the texture of food; thus, it increases the food appearance, such as in meatballs, wet noodles, and crackers (Ferawati et al., 2017). Meatballs that are added with borax have distinctively elasticity than meatballs without borax. While formalin is often mixed in foods such as noodles, tofu, processed meat products (meatballs, nuggets), fish, milk, and fruits as preservatives (Akter and Bari, 2018). Formalin in the body causes respiratory tract cancer and increases the risk of leukemia, with the threshold formalin in the body $0.2 \mathrm{mg} / \mathrm{kg}$ of body weight (Lathifah et al., 2019). Consumption of foods containing borax can cause poisoning and even death if consumed 15-20 $\mathrm{g}$ of borax in adults (Astuti and Nugroho, 2017).

Liquid smoke is the product of wood pyrolysis condensation which contains a large group of phenolic, carbonyl, and acid compounds generated by the pyrolysis process of the wooden constituent, such as cellulose, hemicellulose, and lignin (Martinez et al., 2004; Mohan et al., 2006; Lingbeck et al., 2014; Hadanu and Apituley, 2016). Compounds containing liquid smoke are both volatile and non-volatile which has different functional properties of the smoked product (Lingbeck et al., 2014). Liquid smoke food processing has been known since our predecessors as a method of preserving meat and fish (Lasindrang, 2017). Smoke can penetrate through the foods containing high protein. Besides, the aromatic compound in the smoke may provide additional flavor and colors to the food, and it can also act as antioxidants and bacteriostatic (Soares et al., 2016). 
The use of liquid smoke is safer than traditional smoking methods because the residual PAH (Polycyclic Aromatic Hydrocarbon) compound can be removed by purification using re-distillation (Saloko et al., 2014). Besides, tar residue and PAH compounds such as benzopyrene that are accumulated in the products may have harmful effects on the consumers' health (Simon et al., 2005). For such reason, with the technology of liquid smoke, the application of flavored smoke to the food is more practical as it can be done only by dipping or putting the food products into liquid smoke. It means that smoking can take place easily, fast, and under controlled. Highly purified liquid smoke can be applied to the food since this product is safe, and it has been registered in SNI 01-7152-2006 on Food Additives - Flavor Requirements and its usage in the Food Products.

Various research have already been carried out on the functional properties of liquid smoke which may produce antioxidant effects, antimicrobial activity, and sensory organoleptic quality (Indiarto et al., 2012; Lingbeck et al., 2014). However, research related to the ability of liquid smoke as a natural bio-preservative substitute for borax and formalin in meatballs, so far less studied. Microbiological and physico-chemical properties are the most important elements for assessing the quality of processed meat products. Microbiological and physical-chemical properties are influenced by many factors, one of which is the interaction between components in smoke and food products (Lingbeck et al., 2014). Many researchers have published the texture of fresh meat as well as processed meat products.

This study aimed to evaluate the effect of liquid smoke on the quality of beef meatballs during storage, which includes microbiological and physico-chemical properties.

\section{Materials and methods}

\subsection{Materials}

Liquid smoke is produced from the pyrolysis process of coconut shells at a temperature of $400^{\circ} \mathrm{C}$. Redistillation was carried out at temperatures $\leq 150^{\circ} \mathrm{C}$ to purify liquid smoke from $\mathrm{PAH}$ compounds. The content of phenolic, carbonyl, and acid compounds refers to the previous study by Indiarto et al. (2012), respectively (\% $\mathrm{w} / \mathrm{w}) 1.03,15.26$, and 6.05. Pre-rigor beef, tapioca, salt, and ice are used for making meatballs.

\subsection{The production of beef meatballs}

Beef was grounded firstly using a mincer. Then, the second grinding was done using a bowl cutter, and at the same time, it was added with other ingredients such as tapioca, salt, ice, and spices. Meatballs were shaped manually $(\mathrm{D}=2.4-2.5 \mathrm{~cm})$ and taken using a spoon; then, they were put in hot water at $50-60^{\circ} \mathrm{C}$ until they float. The meatballs produced were then boiled at $\mathrm{T}=$ $94 \pm 1^{\circ} \mathrm{C}$ until they were cooked, water used to boil the meatballs was added with liquid smoke in accordance with proper treatment. The meatballs were removed using a drain and put them in a certain place at room temperature for 30 mins, and then they were packed and stored for 2 days at room temperature. The treatments tested were beef meatballs control and beef meatballs with the application of liquid smoke, respectively $1.0 \%$, $1.5 \%, 2.0 \%, 2.5 \%$, and $3.0 \%$.

\subsection{Determination of total microbes in beef meatballs}

The total microbes in beef meatballs were determined using the Total Plate Count (TPC) (CFU/g) method, according to the study Nelce Mailoa et al. (2017), with a few modifications. Total microbes in beef meatballs were determined. A total of $1 \mathrm{~g}$ meatballs pounded with pestle and mortar, dissolved in $9 \mathrm{~mL}$ of physiological sodium chloride solution to obtain a $10^{-1}$ dilution. Next, $1 \mathrm{~mL}$ of the sample solution is pipetted and put into a test tube containing $9 \mathrm{~mL}$ of physiological sodium chloride solution and so on, until a dilution of $10^{-}$ ${ }^{5}$ is obtained. Dilution samples $10^{-3}, 10^{-4}$, and $10^{-5}$ were pipetted $1 \mathrm{~mL}$ and then put into sterile Petri dishes. The petri dish is then added with $15 \mathrm{~mL}$ of PCA media (Plate Count Agar). After the PCA media dries, the Petri dish is kept upside down in an incubator at $30^{\circ} \mathrm{C}$ for $24 \mathrm{hrs}$.

\subsection{Determination of the color of beef meatballs}

The color analysis was performed using the colorimetry method according to research Indiarto et al. (2019a) with Chroma Meter (CR-400, Konica Minolta, Japan). A Color measurement used by Hunter Lab color system consisting of parameters $\mathrm{L}^{*}$ (whiteness or brightness/ darkness), a* (redness/ greenness), and $\mathrm{b}^{*}$ (yellowness/ blueness) (Cho et al., 2019). The total color difference $(\Delta \mathrm{E})$ can be calculated using the formula:

$$
\sqrt{(L *-L o)^{2}+(a *-a o)^{2}+(b *-b o)^{2}}
$$

Where, $L_{0}, a_{0}$, and $b_{0}$ are color values of untreated meatball. The total color difference values are classified into very different $(\Delta \mathrm{E}>3)$, different $(1.5<\Delta \mathrm{E}<3)$, and slightly different $(\Delta \mathrm{E}<1.5)$ (Tiwari et al., 2008).

\subsection{Determination of the $\mathrm{pH}$ of beef meatballs}

The analysis was conducted according to the study Turhan et al. (2014) with a slight modification. A total of $5 \mathrm{~g}$ of beef meatballs pounded with pestle and mortar, then added $50 \mathrm{~mL}$ of distilled water. The solution is allowed to stand for $1 \mathrm{hr}$, the digital pH meter (HI 2210, Hanna Instruments, Inc., USA) is calibrated by dipping the electrodes into a buffer solution of $\mathrm{pH} 7$ and $\mathrm{pH} 4$ at 
$25^{\circ} \mathrm{C}$. The measurement of the $\mathrm{pH}$ value is done with three replications.

\subsection{Determination of the texture profile in beef meatballs}

The texture profile determination refers to previous studies conducted by Indiarto et al. (2012). The texture of the beef meatballs according to proper treatment is analyzed by the compression method of TPA (Texture Profile Analysis) using the texture analyzer (TA. XT Express, Stable Micro Systems, UK). Beef meatball samples are arranged based on their size to reach uniformity cuboid $(\mathrm{cm}) 3 \times 3 \times 3$, and then they are pressed with a probe $\mathrm{P} / 6$ (diameter $6 \mathrm{~mm}$ ). The pre-test speed 1 $\mathrm{mm} / \mathrm{sec}$, test speed $5 \mathrm{~mm} / \mathrm{sec}$, post-test speed $5 \mathrm{~mm} / \mathrm{sec}$, distance $10 \mathrm{~mm}$, trigger force $5 \mathrm{~g}$, and the samples are pressed until 30\% from its original height. Parameters observed include hardness, springiness, cohesiveness, and gumminess. It is obtained from the Exponent Lite Express 6.1.16.0 Software.

Hardness is defined as the first compression cycle's maximum peak force (first bite) and is often replaced by the term firmness. In the TPA macro, this parameter is collected and represented as force 2 (Figure 1). $\mathrm{Kg}$, g, or $\mathrm{N}$ are the units. Springiness refers to the height the food recovers between the end of the first bite and the start of the second bite. Cohesiveness is defined as the ratio of the second compression's positive force area to that of the first compression. Cohesiveness can be measured by mechanical action as the rate at which the material disintegrates. The value of cohesiveness is measured as 4:6/area 1:3 area (Figure 1). This parameter has no units. The gumminess is defined as the product of hardness $\mathrm{x}$ cohesiveness. Based on Figure 1, the gumminess value parameter is calculated as force $2 \mathrm{x}$ (area 4:6/area 1:3). While there are no units for this parameter according to the originator of the method, the force product (in g, kg, or $\mathrm{N}$ )x cohesiveness (no units) should have a force unit.

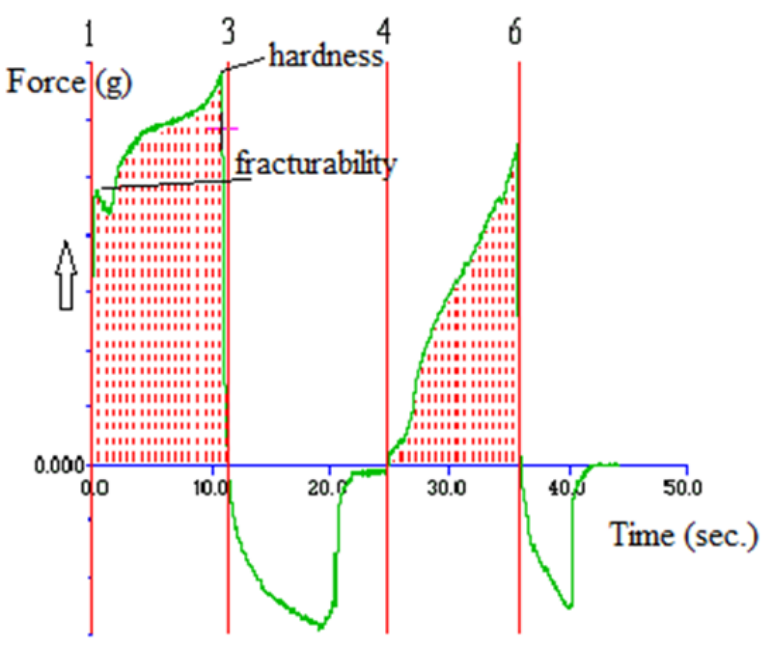

Figure 1. A typical texture profile analysis force-time obtained from texture analyzer (TA. XT Express, Stable Micro Systems, UK)
2.7 Determination water-binding capacity (WBC) of beef meatballs

The determination of WBC has carried according to research Joo (2018) with several modifications.

\subsection{Statistical analysis}

Linear regression analysis was performed using GraphPad software (8.0.2, GraphPad Software, Inc., San Diego, CA) to show the curve of the relationship between storage time $(\mathrm{X})$ and parameters $(\mathrm{Y})$ : $\mathrm{pH}$, total microbial number, hardness, springiness, cohesiveness, and gumminess. Storage time is carried out for two days, with observations every 12 hours. Color parameter data are evaluated by one-way variance analysis, followed by a Tukey's test at $\mathrm{p}<0.05$.

\section{Results}

3.1 Effect of liquid smoke on total microbial of beef meatballs during storage

The results showed that control (without the addition of liquid smoke) and with the addition of liquid smoke $1 \%$ had a significant effect $(p<0.05)$ on total microbes. Figure 2 shows the rate of increase in the total number of microbes by adding $1 \%$ liquid smoke to beef meatballs during storage is slower compared to controls (without the addition of liquid smoke), respectively $902.8 \mathrm{CFU} / \mathrm{g}$ and $2361 \mathrm{CFU} / \mathrm{g}$, with coefficient determination $\left(\mathrm{R}^{2}\right)$ 0.6161 and 0.7173 . This value indicates that the effect of storage time on the total microbial count in beef meatballs was $61.61 \%$, with $1 \%$ liquid smoke added and $71.73 \%$ for control. The remaining percentage is influenced by other variables not observed in this study. According to the Indonesian National Standard (SNI) 013818-1995, the total number of microbes in meatball products, a maximum of $1.0 \times 10^{5} \mathrm{CFU} / \mathrm{g}$. Based on this maximum limit, beef meatballs that have added $1 \%$ liquid smoke can hold up to $48 \mathrm{hrs,} \mathrm{with} \mathrm{a} \mathrm{total} \mathrm{microbial}$ of $9.9 \times 10^{4} \mathrm{CFU} / \mathrm{g}$. While in control, it has a total microbial number of $1.1 \times 10^{5} \mathrm{CFU} / \mathrm{g}$ at initial storage.

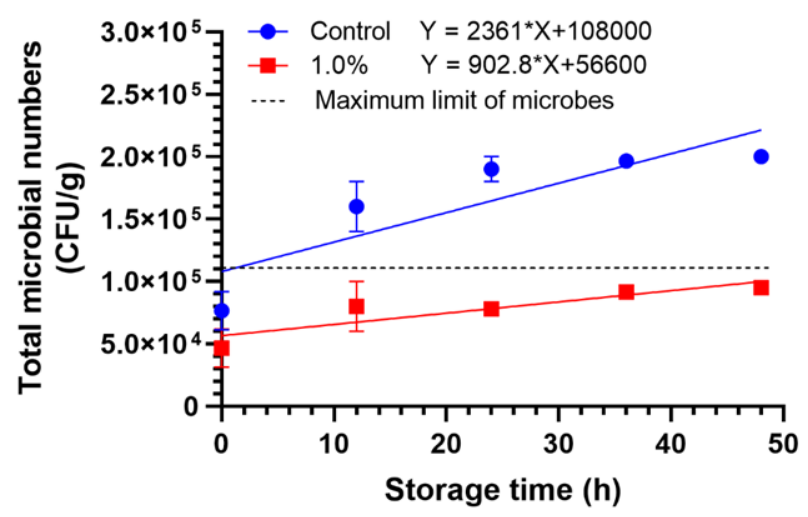

Figure 2. The total microbial numbers of beef meatballs during storage 
This means that the total microbial numbers in control have exceeded the maximum limit required.

\subsection{Effect of liquid smoke on the color of beef meatballs at various concentrations}

Liquid smoke added to beef meatballs has a significant effect $(p<0.05)$ on $L^{*}$ value. The $L^{*}$ value of beef meatballs ranges from 48.73-72.05 (Table 1). Beef meatballs added by $1 \%$ liquid smoke, can significantly reduce the $L^{*}$ value compared to control, which means the meatballs tend to be darker. The $\mathrm{L}^{*}$ value decreased significantly at a concentration of $1.5 \%$. Concentrations of more than $1.5 \%$ do not have significant effects on the impairment of $\mathrm{L}^{*}$. The same result was also shown Indiarto et al. (2012), that increasing the concentration of liquid smoke added to chicken meat, could reduce the $\mathrm{L}^{*}$ value.

The addition of liquid smoke to beef meatballs also had a significant influence $(\mathrm{p}<0.05)$ on the values of $\mathrm{a}^{*}$ and $\mathrm{b}^{*}$. Table 1 shows the $\mathrm{a}^{*}$ values tend to decrease, as an increase in the concentration of liquid smoke added. Decreasing the value of $\mathrm{a}^{*}$ contributes to reducing the intensity of the red color. With the addition of $2.5-3.0 \%$ liquid smoke, $a^{*}$ value was significantly decreased compared to the control and 1\% liquid smoke addition. The highest percentage of $\mathrm{a}^{*}$ value decrease was $55.41 \%$. The value of $\mathrm{b}^{*}$ also has the same pattern as the value of $\mathrm{a}^{*}$, where an increase in the concentration of liquid smoke added can reduce the value of $b^{*}$ (Table 1 ). The $b^{*}$ value that decreases mean that the intensity of the yellow color is getting lower. The percentage of decrease in $\mathrm{b}^{*}$ value is highest at $25.10 \%$. The highest percentage reduction occurred in beef meatballs with $3 \%$ liquid smoke added, compared to controls.

The color parameters $\mathrm{L}^{*} \mathrm{a}^{*}$ and $\mathrm{b}^{*}$ are used to determine the total color difference $(\Delta \mathrm{E})$. Table 1 shows that increasing the concentration of liquid smoke affects the total color difference in beef meatballs significantly. The value of $\Delta \mathrm{E}$ ranges from 5.91-23.41. According to Tiwari et al. (2008), the total color difference in beef meatballs was added liquid smoke is classified as very different. The higher the addition of the concentration of liquid smoke, tends to increase the total color difference in the meatballs. A significant increase occurred in the addition of liquid smoke at a concentration of $1.5 \%$, where the total color difference increased 3.58 times compared to the concentration of $1 \%$. Liquid smoke addition more than $1.5 \%$ tends not to have a significant effect on increasing total color difference.

\subsection{Effect of liquid smoke on the $p H$ of beef meatballs during storage}

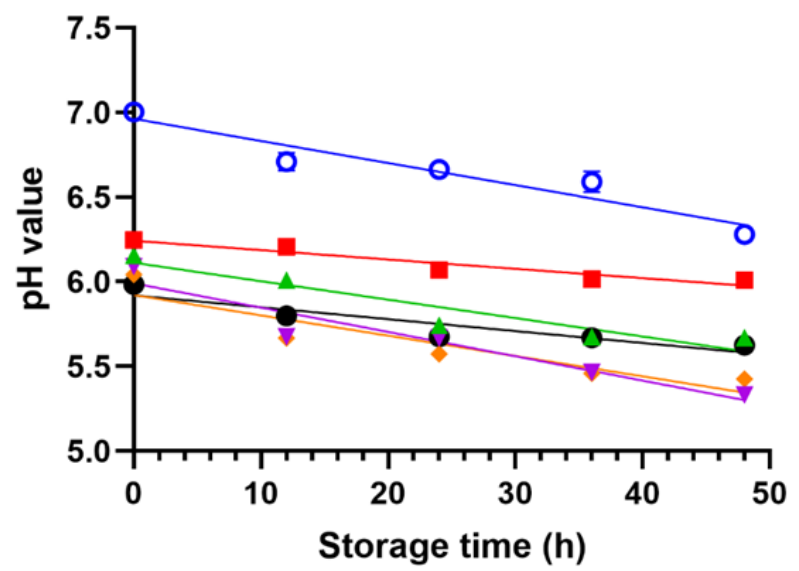

Figure 3. The $\mathrm{pH}$ value of beef meatballs during storage at various concentrations of liquid smoke; control (o); 1.0\% (घ); $1.5 \%(\Delta) ; 2.0 \%(\nabla) ; 2.5 \%(\diamond) ; 3.0 \%(\bullet)$

Figure 3 shows a decrease in the $\mathrm{pH}$ value of beef meatballs at various concentrations of liquid smoke, significantly affected $(\mathrm{p}<0.05)$ by storage time. The relationship between storage time and $\mathrm{pH}$ was carried out using a linear regression equation approach (Figure 3). The influence of beef meatball storage time on $\mathrm{pH}$ values in control and all treatments ranged from $84.44-91.20 \%$ (Table 2). Slope with a negative value; means the $\mathrm{pH}$ value has decreased during storage. The slowest rate of decline $\mathrm{pH}$ obtained on the addition of liquid smoke $1 \%$. At these concentrations, $\mathrm{pH}$ slower rate decreased 2.38fold compared with no addition of liquid smoke. However, the addition of a $2 \%$ concentration showed a higher rate of $\mathrm{pH}$ reduction compared to control. The predicted $\mathrm{pH}$ value at initial storage shows a decrease, along with the increased concentration of liquid smoke added. This is due to acidic liquid smoke with a $\mathrm{pH}$ value of 3.19 .

Table 1. Analysis of the color of beef meatballs at various concentrations of liquid smoke

\begin{tabular}{ccccc}
\hline Treatment & $\mathrm{L}^{*}$ & $\mathrm{a}^{*}$ & $\mathrm{~b}^{*}$ & $\Delta \mathrm{E}$ \\
\hline Control & $72.05 \pm 0.77^{\mathrm{a}}$ & $1.57 \pm 0.07^{\mathrm{a}}$ & $7.17 \pm 0.08^{\mathrm{a}}$ & \\
$1.00 \%$ & $66.14 \pm 0.90^{\mathrm{b}}$ & $1.49 \pm 0.15^{\mathrm{a}}$ & $7.03 \pm 0.21^{\mathrm{a}}$ & $5.91 \pm 0.14^{\mathrm{c}}$ \\
$1.50 \%$ & $50.89 \pm 0.13^{\mathrm{c}}$ & $1.16 \pm 0.11^{\mathrm{ab}}$ & $7.12 \pm 0.36^{\mathrm{a}}$ & $21.17 \pm 0.89^{\mathrm{b}}$ \\
$2.00 \%$ & $49.39 \pm 2.12^{\mathrm{c}}$ & $1.15 \pm 0.03^{\mathrm{ab}}$ & $6.91 \pm 1.26^{\mathrm{ab}}$ & $22.69 \pm 1.34^{\mathrm{ab}}$ \\
$2.50 \%$ & $49.03 \pm 1.63^{\mathrm{c}}$ & $0.77 \pm 0.45^{\mathrm{b}}$ & $5.75 \pm 0.30^{\mathrm{ab}}$ & $23.08 \pm 0.86^{\mathrm{ab}}$ \\
$3.00 \%$ & $48.73 \pm 0.52^{\mathrm{c}}$ & $0.70 \pm 0.32^{\mathrm{b}}$ & $5.37 \pm 0.46^{\mathrm{b}}$ & $23.41 \pm 0.29^{\mathrm{a}}$ \\
\hline
\end{tabular}

Mean \pm standard deviation $(n=3)$. Different superscript letters in the same column indicate significant difference $(\mathrm{p}<0.05)$ based on the Tukey's test. Control: beef meatballs sample without liquid smoke addition. 
Table 2. Regression model statistics for predicting $\mathrm{pH}$ value at various liquid smoke concentrations

\begin{tabular}{cccc}
\hline Treatment & $\mathrm{R}^{2}$ & Intercept & Slope $\left(\times 10^{-2}\right)$ \\
\hline Control & 0.912 & 6.96 & -1.31 \\
$1.00 \%$ & 0.9104 & 6.24 & -0.55 \\
$1.50 \%$ & 0.8826 & 6.11 & -1.09 \\
$2.00 \%$ & 0.9043 & 5.99 & -1.44 \\
$2.50 \%$ & 0.8444 & 5.92 & -1.2 \\
$3.00 \%$ & 0.8474 & 5.92 & -0.7 \\
\hline
\end{tabular}

Control: beef meatballs sample without liquid smoke addition.

\subsection{Effect of liquid smoke on beef meatballs texture profile during storage}

\subsubsection{Hardness}

The relationship between storage time on beef meatballs hardness value in the treatment and control of liquid smoke uses a linear regression equation approach. Storage time significantly affected $(p<0.05)$ hardness level of beef meatballs in the control and all treatments. The influence of storage time on the hardness of beef meatballs ranged between $81.96-97.46 \%$ (Table 4 ). The slope on the control and all treatments are positive; it means the longer storage, an increase in the value of beef meatballs hardness. Figure 4 shows the higher the concentration of liquid smoke added, the hardness value tends to improve. At the initial storage, the hardness prediction value increases with the increasing concentration of liquid smoke added (Table 4). This is indicated by the intercept in the control and all treatments that have increased along with an increase in the concentration of liquid smoke added to beef meatballs. Generally, Table 4 shows the addition of liquid smoke can reduce the rate of increase in hardness on beef meatballs compared to the control, except at a concentration of $1.5 \%$. Meanwhile, the addition of liquid smoke $2.5 \%$ showed the slowest rate of increase in hardness, compared to control and other treatments.

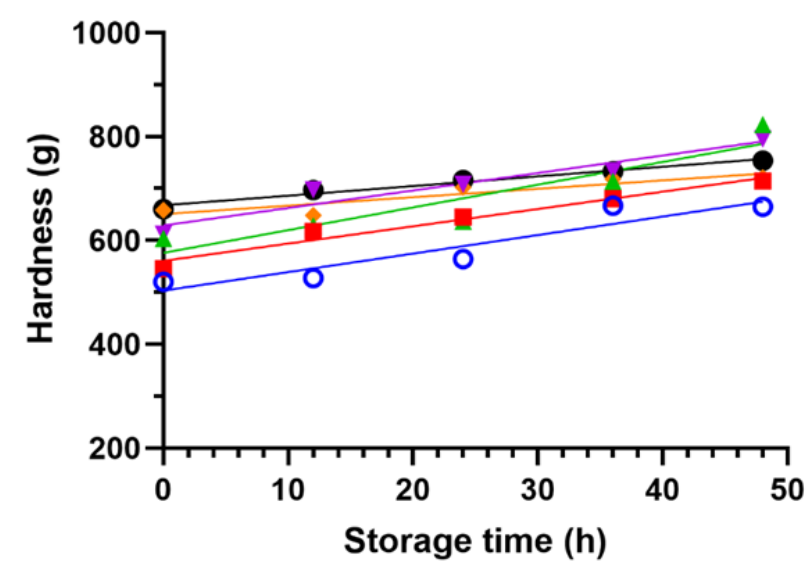

Figure 4. The hardness value of beef meatballs during storage at various concentrations of liquid smoke; control (o); $1.0 \%$ $(\square) ; 1.5 \%(\Delta) ; 2.0 \%(\nabla) ; 2.5 \%(\diamond) ; 3.0 \%(\bullet)$

\subsubsection{Springiness}

The relationship between the storage time on springiness value is obtained using a linear regression equation. The results showed that storage time had a significant effect $(\mathrm{p}<0.05)$ on beef meatball springiness at various concentrations of liquid smoke. Springiness gets higher as storage time increases (Figure 5). The effect of storage time on springiness in control and all treatments ranged from 80.56 to $95.57 \%$, while the remaining percentage was influenced by other variables not examined. At initial storage, the predicted value of springiness increases with increasing liquid smoke concentration added. This is indicated by the value of the intercept. The rate of increase in springiness in beef meatballs is slower with increasing liquid smoke concentration added (Table 4 ). With the addition of $3.0 \%$ liquid smoke, the slowest rate of springiness is increased. The rate is 2.37 -fold slower than the control.

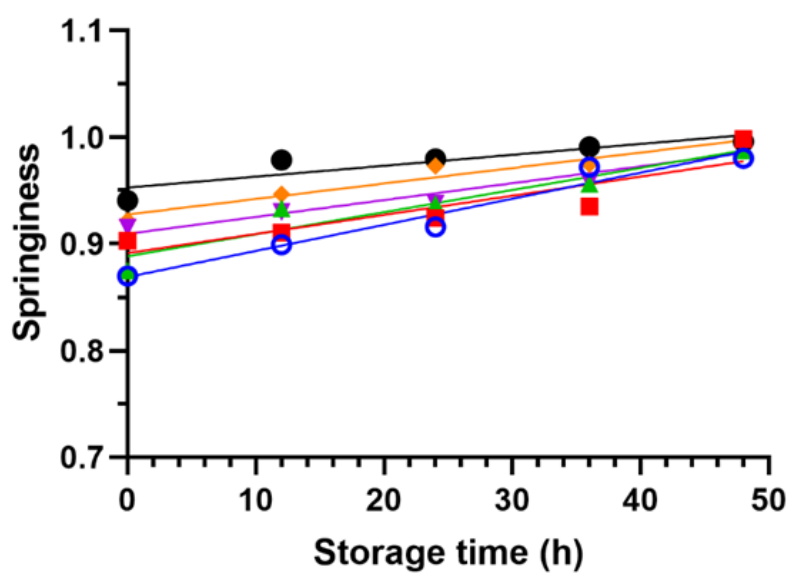

Figure 5. The springiness value of beef meatballs during storage at various concentrations of liquid smoke; control (o); $1.0 \%(\square) ; 1.5 \%(\Delta) ; 2.0 \%(\nabla) ; 2.5 \%(\diamond) ; 3.0 \%(\bullet)$

Table 3. Effect of the addition of liquid smoke on $\%$ of free water volume

\begin{tabular}{cc}
\hline Treatment & $\% \mathrm{mg} \mathrm{H} \mathrm{O}_{2}$ \\
\hline Control & $31.17 \pm 0.43^{\mathrm{a}}$ \\
$1.00 \%$ & $13.93 \pm 0.79^{\mathrm{b}}$ \\
$1.50 \%$ & $12.02 \pm 0.35^{\mathrm{c}}$ \\
$2.00 \%$ & $3.52 \pm 0.28^{\mathrm{d}}$ \\
$2.50 \%$ & $0.88 \pm 0.04^{\mathrm{e}}$ \\
$3.00 \%$ & $0.16 \pm 0.08^{\mathrm{e}}$ \\
\hline
\end{tabular}

Mean \pm standard deviation $(n=3)$. Different superscript letters in the same column indicate significant difference $(p<0.05)$ based on the Tukey's test. Control: beef meatballs sample without liquid smoke addition.

Table 3 shows that the addition of liquid smoke significantly affects $(p<0.05)$ the percentage of beef meatballs free water. The amount of free water decreases, along with the increasing concentration of liquid smoke. The decrease was 2.24-194.81-fold compared to controls. It results in binding capacity of 
Table 4. Regression model statistics for predicting textural measurements at various liquid smoke concentrations

\begin{tabular}{ccccc}
\hline Parameter & Treatment & $\mathrm{R}^{2}$ & Intercept & Slope \\
\hline \multirow{5}{*}{ Hardness } & Control & 0.8782 & 503.4 & 3.57 \\
& $1.00 \%$ & 0.9652 & 560.7 & 3.33 \\
& $1.50 \%$ & 0.8593 & 576.1 & 4.37 \\
& $2.00 \%$ & 0.9235 & 628.8 & 3.37 \\
& $2.50 \%$ & 0.8196 & 650.8 & 1.62 \\
Springiness & $3.00 \%$ & 0.9746 & 667.7 & 1.86 \\
\hline & Control & 0.9557 & 0.87 & $2.44 \times 10^{-3}$ \\
& $1.00 \%$ & 0.8056 & 0.89 & $1.79 \times 10^{-3}$ \\
& $1.50 \%$ & 0.9077 & 0.89 & $2.07 \times 10^{-3}$ \\
& $2.00 \%$ & 0.9181 & 0.91 & $1.58 \times 10^{-3}$ \\
& $2.50 \%$ & 0.9446 & 0.93 & $1.45 \times 10^{-3}$ \\
Cohesiveness & $3.00 \%$ & 0.8018 & 0.95 & $1.03 \times 10^{-3}$ \\
\hline \multirow{5}{*}{ Gumminess } & Control & 0.9629 & 0.56 & $1.72 \times 10^{-3}$ \\
& $1.00 \%$ & 0.902 & 0.49 & $3.50 \times 10^{-3}$ \\
& $1.50 \%$ & 0.8734 & 0.57 & $2.31 \times 10^{-3}$ \\
& $2.00 \%$ & 0.7136 & 0.55 & $1.20 \times 10^{-3}$ \\
& $2.50 \%$ & 0.8779 & 0.46 & $2.58 \times 10^{-3}$ \\
& $3.00 \%$ & 0.8871 & 0.56 & $5.69 \times 10^{-4}$ \\
\hline \multirow{5}{*}{ Control } & 0.9753 & 306.9 & 1.81 \\
& $1.00 \%$ & 0.947 & 276.5 & 4.05 \\
& $2.00 \%$ & 0.9618 & 347 & 3.23 \\
& $2.50 \%$ & 0.9108 & 384.4 & 0.88 \\
& $3.00 \%$ & 0.8682 & 315.1 & 2.17 \\
& 0.9142 & 380.4 & 1.08 \\
\hline
\end{tabular}

Control: beef meatballs sample without liquid smoke addition.

liquid smoke treatment is more than the control due to cohesiveness ranged from 71.36 to $96.29 \%$, which is the presence of phenolic compounds in liquid smoke. indicated by the coefficient of determination $\left(\mathrm{R}^{2}\right)$. At the Thus it affects the springiness value. The percentage of initial storage shows cohesiveness predictions ranged the volume of free water that comes out, the less free water means that water-binding capacity will increase (Table 3).

\subsubsection{Cohesiveness}

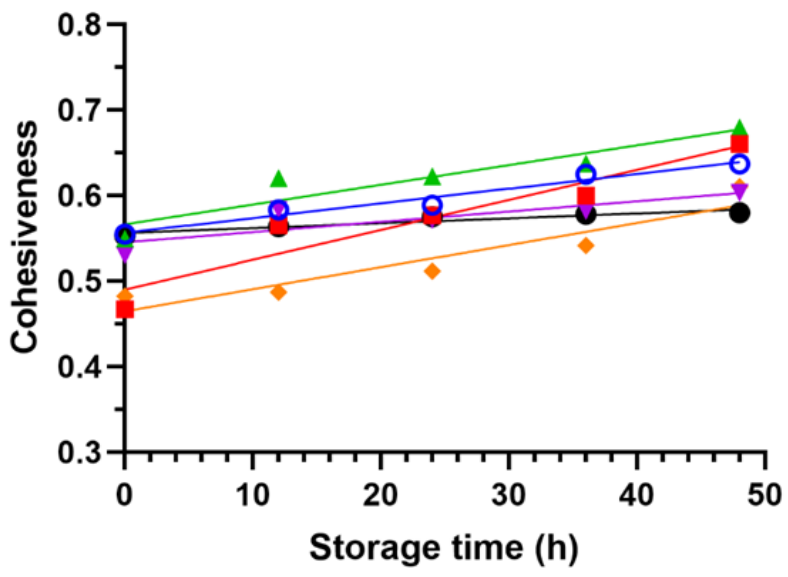

Figure 6. The cohesiveness value of beef meatballs during storage at various concentrations of liquid smoke; control (o); $1.0 \%(\square) ; 1.5 \%(\Delta) ; 2.0 \%(\nabla) ; 2.5 \%(\diamond) ; 3.0 \%(\bullet)$

The relationship between the storage time on cohesiveness value is obtained using a linear regression equation shown in Figure 6. Storage time significantly $(p<0.05)$ influences beef meatball cohesiveness in the control and all treatments, except for the addition of $2.0 \%$ liquid smoke. The effect of storage time on from 0.46-0.56. Increasing the concentration of liquid smoke does not show the pattern of increase or decrease cohesiveness. However, in Table 4 shows that the longer the storage time of beef meatballs, the cohesiveness increases at different rates. The fastest and slowest cohesiveness improvement rates were obtained by adding liquid smoke $1.0 \%$ and $3.0 \%$, respectively.

\subsubsection{Gumminess}

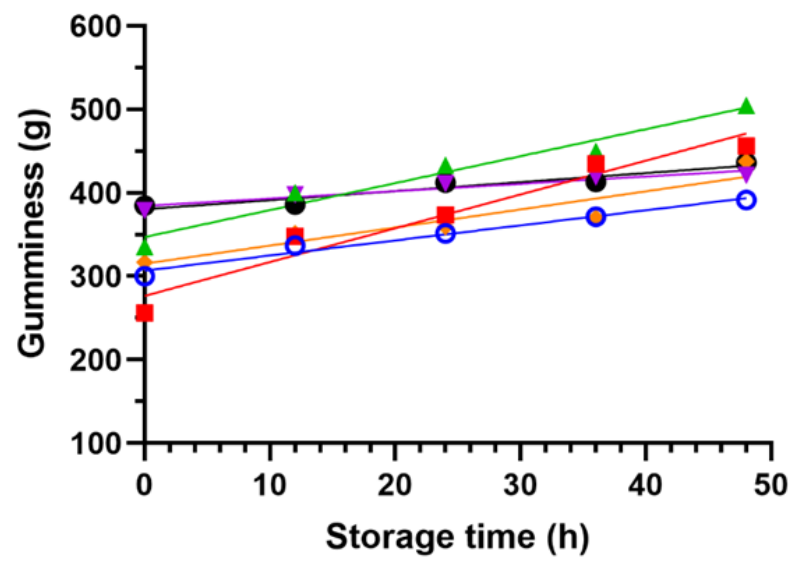

Figure 7. The gumminess value of beef meatballs during storage at various concentrations of liquid smoke; control (o); $1.0 \%(\square) ; 1.5 \%(\Delta) ; 2.0 \%(\nabla) ; 2.5 \%(\diamond) ; 3.0 \%(\bullet)$

The relationship between the storage time on gumminess value is obtained using a linear regression equation. The relationship curve between the storage 
time of the gumminess values is represented in Figure 7. Storage time significantly affected $(p<0.05)$ on the gumminess value of beef meatballs. In Table 4 , it shows that $86.82-97.53 \%$, the increase in gumminess is affected by storage time. At the initial storage, the predicted gumminess values ranged from 276.50 to $384.40 \mathrm{~g}$. The lower of the predictive value of gumminess, the rate of increase is accelerating (Table 4).

\section{Discussion}

Beef meatballs are processed meat products, which are classified as perishable food. This is due to beef meatballs easily damaged due to microbiological, chemical, and physical factors. Innovation is needed to maintain the quality of beef meatballs during storage, one of which uses liquid smoke as a preservative. Liquid smoke is the result of condensation from wood pyrolysis containing cellulose, hemicellulose, and lignin (Lingbeck et al., 2014). The mechanism of the wood pyrolysis process consists of 4 stages, starting with water evaporation, followed by hemicellulose decomposition, cellulose decomposition, and finally lignin decomposition. Hemicellulose and cellulose pyrolysis occur between $180-350^{\circ} \mathrm{C}$, producing carboxylic acids and carbonyl compounds, then decomposition of lignin between $300-500^{\circ} \mathrm{C}$, producing phenolic compounds (Simon et al., 2005). The difference in the composition of wood constituents affects the physical and chemical characteristics of the liquid smoke produced.

In addition to phenolic compounds, carbonyl, and acids, wood pyrolysis also produces dangerous compounds of polycyclic aromatic hydrocarbon (PAH) groups such as benzo(a)pyrene. $\mathrm{PAH}$ compounds are formed at a temperature of $500-900^{\circ} \mathrm{C}$. In pregnant rats exposed to more than $300 \mathrm{ppm}$ in food, polycyclic aromatic hydrocarbons, particularly benzo(a)pyrene compounds, are shown to cause congenital disabilities. While foods containing levels above $900 \mathrm{ppm}$ in test animals cause liver and blood defects (Lingbeck et al., 2014). Regulation of the European Union (EU) has limited the amount of PAHs that are allowed in the food of $0.002 \mathrm{ppm}$ (Dolan et al., 2010). Although PAH is toxic and has low water solubility, separation of the $\mathrm{PAH}$ compound can be done easily, using phase separation, filtration or distillation techniques (Darmadji, 2002; Simon et al., 2005). In this study used liquid smoke that has been purified from PAH residues using the redistillation technique.

The acid compounds in liquid smoke such as acetic acid, propionate, butyric and valeric can affect the flavor, pH and shelf life of food ( Montazeri et al., 2013; Lingbeck et al., 2014). Acid compounds, especially acetic acid, have antimicrobial activity. At a concentration of $5 \%$, the compound has a bactericidal effect. Acetic acid can penetrate cell walls and efficiently neutralize the transmembrane $\mathrm{pH}$ gradient. Phenolic and acid compounds, working synergistically with bactericidal and bacteriostatic properties, cause bacterial cell proteins to be denatured so that the hydrophobic bonding components of the cell membrane such as protein and phospholipids are damaged. This causes an increase in cell permeability, thus allowing the entry of phenolic compounds and organic ions into the cell, and the release of cell substances such as proteins and nucleic acids that result in cell death (Minatel et al., 2017)

The carbonyl compound in liquid smoke contributes to the golden-brown color of the product. Interaction between carbonyl compounds (mainly glycolaldehyde and methylglyoxal) and amino groups in meat causes color changes with the formation of golden-brown color and Maillard reaction in the product (Varlet et al., 2007). Besides, phenolic compounds also contribute to the color, although these compounds mainly contribute to the smoky taste and aroma, also have antibacterial and antioxidant properties (Varlet et al., 2010; Indiarto et al., $2019 \mathrm{~b}$ ). Cooking at temperature $\geq 70-80^{\circ} \mathrm{C}$ also causes a golden brown color because myoglobin is denatured (Hicks et al., 2018).

The $\mathrm{pH}$ value decreases with storage time due to oxidation of fat in the meat. The oxidation process can reduce $\mathrm{pH}$, nutritional value, and quality of meat during storage, due to the decomposition of fatty acids in meat (Amaral et al., 2018). Decomposition of unsaturated fatty acids into saturated fatty acids, causing the formation of short-chain fatty acids and accumulates in large quantities (Den Besten et al., 2013). Liquid smoke has acidic properties, thus the higher the concentration of liquid smoke added, the $\mathrm{pH}$ value of the smoked product will be lower (acid). The low $\mathrm{pH}$ values will cause an increase in the hardness rate (Montazeri et al., 2013). According to Öztürk and Serdarog lu (2015), the meat having lower $\mathrm{pH}$ causes protein denaturation so that it has a higher level of hardness. The hardness increase of smoked products is caused by the reaction between smoke constituents and protein that causes the loss of water in the product (Tóth and Potthast, 1984). In this study, hardness values in liquid smoke treatment and control have a value of $\leq 1820 \mathrm{~g}$. According to Cavitt et al. (2005), food products that have hardness values of $\leq 1820$ are categorized into extremely tender. It shows that the meatballs with liquid smoke treatment and control are still in a tender category.

According to Abustam et al. (2015), the higher 
concentration of liquid smoke added increases the waterbinding capacity which may affect elasticity. The increased of smoke liquid concentration added causes the increase of phenolic content in beef meatballs. Derived phenolic compounds can form a hydrogen bond with water, which may affect the water-binding capacity to meat (Maga, 1987). The increase of water-binding capacity and the increase of the concentration of liquid smoke indicate that liquid smoke plays a role in loosening the bound of myofibrils fiber to form space that is filled with water in a semi-freeform thus water the ability of the meat to bind water increases; as a result, the elasticity increases (Abustam et al., 2016). It is in accordance with this study, in which Table 3 shows that the higher the concentration of liquid smoke added, the less the amount of free water so that water-binding capacity increases. This makes the beef meatballs have a high value of springiness. The addition of liquid smoke can increase meatballs elasticity compared to those without liquid smoke treatment (Abustam et al., 2015).

Cohesiveness increases in smoked products due to the chemical reaction between the smoke constituents with protein causes the loss of stored water; thus, the stored meatballs have a more compact texture (Tóth and Potthast, 1984). Research on loin and bacon conducted by Martinez et al. (2004), stated that the application of liquid smoke that is rich in phenolic derivatives compound would provide an increase in the value of hardness, fracturability, cohesiveness, chewiness, and gumminess during the storage. The reason is that in hardness and cohesiveness parameters, the liquid smoke treatment is higher compared to those in controls; thus, it affects meatballs gumminess. The research on loin conducted by Martinez et al. (2004), shows that the application of liquid smoke that is rich in phenolic derivatives compound will give the significant difference to the loin that is not applied with the liquid smoke in term of their parameters of hardness, fracturability, cohesiveness, chewiness, and gumminess.

\section{Conclusion}

The storage time significantly has a negative effect on the $\mathrm{pH}$ value but has a positive effect on the total microbial number and texture parameters (hardness, springiness, cohesiveness, and gumminess). Increasing the concentration of liquid smoke added on beef meatballs can significantly decrease the rate of damage, caused by microbes, and maintains the texture during storage and be able to increase the total color difference, compared with no addition of liquid smoke. So that liquid smoke can be used as natural preservatives alternative, which is safe in beef meatballs. However, it must be considered about consumers' preference for the smoky aroma and flavor obtained.

\section{Conflict of Interest}

The authors declared no conflict of interest.

\section{Acknowledgments}

The authors would like to thanks the Universitas Padjadjaran for the financial support during this research via the project grant of Penelitian Dosen Muda.

\section{References}

Abustam, E., Yusuf, M., Ali, H.M. and Yuliati, F.N. (2015). Effect of muscle types of bali beef pre and post rigor on the quality of meatballs during storage. Pakistan Journal of Nutrition, 14(3), 170-173. https://doi.org/10.3923/pjn.2015.170.173

Abustam, E., Yusuf, M. and Said, M. (2016), Substitution of Phospate with Liquid Smoke as a Binder on the Quality of Chicken Nugget. World Academy of Science, Engineering and Technology International Journal of Nutrition and Food Engineering, 10(10), 661-665.

Akter, B. and Bari, L. (2018). Determination of formaldehyde in commercial noodles collected from dhaka city, bangladesh, by high performance liquid chromatography. Annals. Food Science and Technology, 19(2), 341-348.

Amaral, A.B., Solva, M.V.D. and Lannes, S.C.D.S. (2018). Lipid oxidation in meat: Mechanisms and protective factors - a review. Food Science and Technology, 38(Suppl. 1), 1-15. https:// doi.org/10.1590/fst.32518

Astuti, E.D. and Nugroho, W.S. (2017). Capability of Curcumax reagent to detect borax in boiled meatballs. Jurnal Sain Veteriner, 35(1), 42. https:// doi.org/10.22146/jsv.29289

Den Besten, G., Van Eunen, K., Groen, A.K., Venema, K., Reijngoud, D.J. and Bakker, B.M. (2013). The role of short-chain fatty acids in the interplay between diet, gut microbiota, and host energy metabolism. Journal of Lipid Research, 54, 23252340. https://doi.org/10.1194/jlr.R036012

Cavitt, L.C., Xiong, R. and Owens, C.M. (2005). Changes in Tenderness of Broiler Breast Fillets", Journal of Muscle Foods, 16(3), 223-242. https:// doi.org/10.1111/j.1745-4573.2005.00001.x

Cho, S.W., Ko, H.S., Kim, C., Kang, C.S. and Park, C.S. (2019). Effect of flour color and starch pasting properties on color of noodle dough sheet and texture of cooked noodles in Korean wheat cultivars. 
International Journal of Agriculture and Biology, 21, 271-281.

Darmadji, P. (2002). Optimation of Liquid Smoke Purification by Redistilation Method. Jurnal Teknol. Dan Industri Pangan, 12, 267-271.

Dolan, L.C., Matulka, R.A. and Burdock, G.A. (2010). Naturally Occurring Food Toxins. Toxins, 2(9), 2289 -2332. https://doi.org/10.3390/toxins2092289

Ferawati, Purwanto, H., Kurnia, Y. and Purwati, E. (2017). Microbiological Quality and Safety of Meatball Sold in Payakumbuh City, West Sumatra, Indonesia. World Academy of Science, Engineering and Technology International Journal of Nutrition and Food Engineering, 11, 337-341.

Hadanu, R. and Apituley, D.A.N. (2016). Volatile Compounds Detected in Coconut Shell Liquid Smoke through Pyrolysis at a Fractioning Temperature of $350-420^{\circ} \mathrm{C}$. Makara Journal of Science, 20(3), 95-100. https://doi.org/10.7454/ mss.v20i3.6239

Hicks, Z.M., Yancey, J.W.S., Apple, J.A. and Johnson, T.M. (2018), Cooking from a Frozen State, Endpoint Temperature, and Postcookery Chilling Affect Internal and External Color and Cooking Losses in Ground Beef Patties. Journal of Animal Science, 95 (Suppl. 2), 187 https://doi.org/10.2527/ asasmw.2017.387

Indiarto, R., Nurhadi, B. and Subroto, E. (2012). Study of characteristics texture (texture profile analysis) and organoleptic smoked chicken based on liquid smoke technology from coconut shell. Jurnal Teknologi Hasil Pertanian, 5, 106-116.

Indiarto, R., Pranoto, Y., Santoso, U. and Supriyanto. (2019a), Evaluation of Physicochemical Properties and Antioxidant Activity of Polyphenol-Rich Cacao Bean Extract Through Water Blanching. Pakistan Journal of Nutrition, 18, 278-287. https:// doi.org/10.3923/pjn.2019.278.287

Indiarto, R., Pranoto, Y., Santoso, U. and Supriyanto. (2019b). In vitro antioxidant activity and profile of polyphenol compounds extracts and their fractions on cacao beans. Pakistan Journal of Biological Sciences, 22(1), 34-44. https://doi.org/10.3923/ pjbs.2019.34.44

Joo, S.T. (2018). Determination of water-holding capacity of porcine musculature based on released water method using optimal load. Korean Journal for Food Science of Animal Resources, 38, 823-828.

Lasindrang, M. (2017). Potential of Liquid Smoke from Palm Kernel Shell as Biopreservative to Tuna (Thunnus sp) Fish Protein. Indonesian Food and Nutrition Progress, 14, 59. https://doi.org/10.22146/ ifnp. 24281

Lathifah, Q.A., Turista, D.D.R., Azizah, L. and Khulaifi, A.E. (2019). Identification of Formalin and Borax on Tuna in Ngemplak Market Tulungagung. Melysa (Medical Laboratory Analysis and Sciences Journal), 1, 1-5. https://doi.org/10.35584/ melysa.v1i1.15

Lingbeck, J.M., Cordero, P., O’Bryan, C.A., Johnson, M.G., Ricke, S.C. and Crandall, P.G. (2014), Functionality of liquid smoke as an all-natural antimicrobial in food preservation. Meat Science, 97 (2), 197-206. https://doi.org/10.1016/ j.meatsci.2014.02.003

Maga, J.A. (1987). The flavor chemistry of wood smoke. Food Reviews International, 3(1-2), 139-183. https://doi.org/10.1080/87559128709540810

Martinez, O., Salmerón, J., Guillén, M.D. and Casas, C. (2004). Texture profile analysis of meat products treated with commercial liquid smoke flavourings. Food Control, 15(6), 457-461. https:// doi.org/10.1016/S0956-7135(03)00130-0

Minatel, I.O., Borges, C.V., Ferreira, M.I., Gomez, H.A.G., Chen, C.-Y.O. and Lima, G.P.P. (2017). Phenolic Compounds: Functional Properties, Impact of Processing and Bioavailability. In SotoHernandez, M., Palma-Tenango, M. and GarciaMateos, M.D.R. (Eds.). Phenolic Compounds: Biological Availability. IntechOpen E-book. https:// doi.org/10.5772/66368

Mohan, D., Pittman, C.U. and Steele, P.H. (2006). Pyrolysis of Wood/Biomass for Bio-oil: A Critical Review. Energy and Fuels, 20, 848-889. https:// doi.org/10.1021/ef0502397

Montazeri, N., Oliveira, A.C.M., Himelbloom, B.H., Leigh, M.B. and Crapo, C.A. (2013), Chemical characterization of commercial liquid smoke products. Food Science and Nutrition, 1(1), 102115. https://doi.org/10.1002/fsn3.9

Nelce Mailoa, M., Marthina Tapotubun, A. and Matrutty, T.E.A.A. (2017). Analysis Total Plate Counte (TPC) on Fresh Steak Tuna Applications Edible Coating Caulerpa sp during Stored at Chilling Temperature. IOP Conference Series: Earth and Environmental Science, 89,012014. https://doi.org/10.1088/17551315/89/1/012014

Öztürk, B. and Serdaroglu, M. (2015). Quality characteristics of PSE-like Turkey Pectoralis major muscles generated by high post-mortem temperature in a local Turkish slaughterhouse. Korean Journal for Food Science of Animal Resources, 35(4), 524532. https://doi.org/10.5851/kosfa.2015.35.4.524

Saloko, S., Darmadji, P., Setiaji, B. and Pranoto, Y. 
(2014). Antioxidative and antimicrobial activities of liquid smoke nanocapsules using chitosan and maltodextrin and its application on tuna fish preservation. Food Bioscience, 7, 71-79. https:// doi.org/10.1016/j.fbio.2014.05.008

Simon, R., de la Calle, B., Palme, S., Meier, D. and Anklam, E. (2005). Composition and analysis of liquid smoke flavouring primary products. Journal of Separation Science, 28(9-10), 871-882. https:// doi.org/10.1002/jssc.200500009

Soares, J.M., da Silva, P.F., Puton, B.M.S., Brustolin, A.P., Cansian, R.L., Dallago, R.M. and Valduga, E. (2016). Antimicrobial and antioxidant activity of liquid smoke and its potential application to bacon. Innovative Food Science and Emerging Technologies, 38(Part A), 189-197. https:// doi.org/10.1016/j.ifset.2016.10.007

Tiwari, B.K., Muthukumarappan, K., O’Donnell, C.P. and Cullen, P.J. (2008). Effects of sonication on the kinetics of orange juice quality parameters. Journal of Agricultural and Food Chemistry, 56, 2423-2428. https://doi.org/10.1021/jf073503y

Tóth, L. and Potthast, K. (1984). Chemical Aspects of the Smoking of Meat and Meat Products. Advances in Food Research, 29, 87-158. https:// doi.org/10.1016/S0065-2628(08)60056-7

Turhan, S., Yazici, F., Saricaoglu, T., Mortas, M. and Genccelep, H. (2014). Evaluation of the nutritional and storage quality of meatballs formulated with bee pollen. Korean Journal for Food Science of Animal Resources, 34(4), 423-433. https://doi.org/10.5851/ kosfa.2014.34.4.423

Varlet, V., Prost, C. and Serot, T. (2007). Volatile aldehydes in smoked fish: Analysis methods, occurence and mechanisms of formation. Food Chemistry, 105(4), 1536-1556. https:// doi.org/10.1016/j.foodchem.2007.03.041

Varlet, V., Serot, T. and Prost, C. (2010). Smoke flavoring technology in seafood., p. 233-254. Handbook of Seafood and Seafood Products Analysis. USA: CRC Press. https:// doi.org/10.1201/9781420046359-c15 